\title{
REKONSTRUKSI BATAS USIA PERKAWINAN ANAK DALAM HUKUM NASIONAL INDONESIA
}

\author{
Nur Fadhilah dan Khairiyati Rahmah \\ STAIN Tulungagung dan Kementerian Agama Kabupaten Buton \\ Email: nurfafiya@yahoo.com
}

\begin{abstract}
Abstrak
Konsep batasan usia perkawinan anak dalam fikih bervariasi. Begitu pula terjadi inkonsistensi konsep batasan usia perkawinan dalam peraturan perundang-undangan, sehingga upaya merekonstruksi batas usia perkawinan dalam hukum nasional Indonesia perpektiffikih perlu segera dilakukan dengan cara: Pertama, upaya penyeragaman usia anak dalam peraturan perundang-undangan; Kedua, Pemberian izin dispensasi dengan syarat yang ketat dan sebaiknya diberi batas usia minimal dispensasi yakni usia 16 tahun bagi perempuan dan 19 tahun bagi laki-laki. Kedua konsep ini, dilihat dalam bingkai maslahah yang menjadi tujuan hukum Islam (maqashid al-syari'ah).

The concept of age limitation to marry for children in figh is varied. There is also an inconsistency on the marriage age limitation in regulation. Therefore, it is a need to reconstruct the concept in Indonesian national law based on figh perspective through these following steps; first, there is an effort to make similar limitation on age to marry in regulation; second, the issuing of age dispensation under strict requirements such as giving the limit 16 years old for woman and 19 years old for man. Both of the concept can be look at the merit frame which is the objective of Islamic law (maqashid al-syari'ah).
\end{abstract}

Kata kunci: rekonstruksi, usia, perkawinan

Salah satu pembaruan dalam undangundang perkawinan adalah penetapan batas minimum usia seseorang untuk melakukan perkawinan, sebagaimana disebutkan dalam pasal 7 Undang-undang R.I No. 1 Tahun 1974: "Perkawinan hanya diizinkan jika pihak pria sudah mencapai umur 19 tahun dan pihak wanita sudah mencapai umur 16 tahun". ${ }^{1}$

\footnotetext{
'Sebagaimana diketahui bahwa perjuangan pemerintah untuk mensahkan UUP sangatlah besar, karena pembaruan hukum Islam dalam bidang perkawinan ini memancing reaksi keras umat Islam. RUU perkawinan dianggap bertentangan dengan ajaran-ajaran Islam, bahkan ada anggapan yang lebih keras lagi, RUU tersebut ingin mengkristenkan umat Islam. Dilembaga legislatif, FPP (Fraksi Persatuan Pembangunan) adalah fraksi yang sangat keras menentang RUU tersebut, karena bertentangan dengan fikih Islam. Kamal Hasan menggambarkan
}

Sedangkan dalam Alquran dan hadis tidak menyebutkan secara spesifik tentang batas usia minimum untuk menikah. Persyaratan umum yang lazim dikenal adalah sudah balig, berakal sehat, mampu membedakan yang baik dengan yang buruk sehingga dapat memberikan persetujuannya untuk menikah. Alquran surah al-Nisa/4: 6 menggambarkan bahwa semua ulama baik dari kalangan tradisionalis maupun modernis, dari Aceh sampai Jawa Timur menolak RUU tersebut. Setelah dilakukan lobbyinglobbying antara tokoh-tokoh Islam dengan pemerintah untuk menghilangkan beberapa pasal yang dianggap bertentangan dengan ajaran Islam, barulah kemudian RUU tersebut disepakati. Lebih lanjut lihat Kamal Hasan, "Modernisasi Indonesia; Respon Cendekiawan Muslim," dalam Amiur Nuruddin dan Azhari Akmal Tarigan, Hukum Perdata Islam di Indonesia; Studi Kritis Perkembangan Hukum Islam dari Fikih, UU No. 1/1974 sampai KHI, Edisi Pertama (Cet. III; Jakarta: Kencana, 2006), h. 23-24. 
sampainya waktu seseorang untuk menikah (bulug al-nikah), dengan kata "rusyd".

Kata bulug al-nikah dalam ayat tersebut ditafsirkan oleh para ulama berbeda-beda. Perbedaan ini dikarenakan tinjauan atau sudut pandang masing-masing, Pertama, ditafsirkan sebagai kecerdasan karena tinjauannya dititikberatkan pada segi mental, yakni dilihat pada sikap dan tingkah laku seseorang. Kedua, ditafsirkan cukup umur dan bermimpi, fokus tinjauannya pada fisik lahiriah dan sekaligus telah mukalaf. ${ }^{2}$ Sedangkan dalam hadis, model perkawinan pada usia sebelum balig dipraktekkan oleh Rasulullah saw., dengan menikahi Aisyah r.a ketika berusia enam tahun dan menggaulinya pada usia sembilan tahun".

Baik ayat maupun hadis tersebut, memberi peluang melakukan interpretasi. Kondisi ini menyebabkan para fukaha berbeda pendapat dalam menetapkan batas minimal usia perkawinan. Sesuatu yang wajar terjadi, karena masalah pernikahan di samping wilayah ibadah (ubudiyyah), juga merupakan urusan hubungan antar manusia (mu'amalah) yang oleh agama hanya diatur dalam bentuk prinsip-prinsip umum, maka kedewasaan untuk menikah termasuk masalah ijtihadiyyah, ${ }^{3}$ artinya terbuka peluang bagi manusia untuk menggunakan nalar, menyesuaikannya dengan kondisi sosial dan kultur yang berbeda antara satu daerah dengan daerah yang lain.

Terkait hal tersebut, maka pemerintah Republik Indonesia sebagai penyelenggara negara memiliki kewajiban untuk mengatur negara dan masyarakat berlandaskan Pancasila dan UUD 1945. ${ }^{4}$ Mengingat hukum

${ }^{2}$ Lihat Zaki Fuad Chalil, “Tinjauan Batas Minimal Usia Kawin; Studi Perbandingan Antara Kitab-Kitab Fikih dan Undang-Undang Perkawinan di NegaraNegara Muslim," Mimbar Hukum VII, no. 26 (1996) h. 70.

'Lihat Helmi Karim, "Kedewasaan Untuk Menikah" dalam Chuzaimah T. Yanggo dan Hafiz Anshary, Problematika Hukum Islam Kontemporer (Cet. II; Jakarta: Pustaka Firdaus, 1996), h. 67.

${ }^{4} \mathrm{Hal}$ ini perlu ditegaskan kembali, mengingat bahwa negara Indonesia bukan negara teokrasi dan bukan pula negara sekuler, tetapi negara Pancasila yang bertanggungjawab terhadap eksistensi agama, yang mengatur tentang perkawinan tersebut adalah Undang-undang R.I No. 1 Tahun 1974 dan KHI, maka ketentuan dalam peraturan perundang-undangan inilah yang harus ditaati oleh semua golongan masyarakat yang ada di Indonesia.

Meskipun Undang-undang R.I. No. 1 Tahun 1974 tentang Perkawinan telah diberlakukan selama 34 tahun, yang disusul kemudiandenganterbitnyaInstruksiPresiden R.I No. 1 Tahun 1991 tentang Penyebarluasan KHI, namun masih banyak pelanggaran pernikahan yang law enforcement-nya sangat lemah. Salah satu pelanggaran mengenai hal ini adalah kasus-kasus pernikahan usia anak. Sementara perkawinan merupakan suatu peristiwa hukum. Sebagai suatu peristiwa hukum maka subjek hukum yang melakukan peristiwa tersebut harus memenuhi syarat. Salah satu syarat manusia sebagai subjek hukum untuk dapat dikatakan cakap melakukan perbuatan hukum adalah harus sudah dewasa. ${ }^{5}$ Jadi, kedewasaan menjadi ukuran boleh tidaknya seseorang melakukan tindakan hukum.

kehidupan beragama, dan kerukunan hidup umat beragama guna mencapai tujuan pembangunan nasional, lihat Ahmad Sukardja, "Keberlakuan Hukum Agama dalam Tata Hukum Indonesia" dalam Cik Hasan Bisri, eds., Hukum Islam dalam Tatanan Masyarakat Indonesia (Cet.I; Jakarta: Logos, 1998), h. 26.

$5 \quad$ Usia dewasa yang ditetapkan oleh perundangundangan di Indonesia bervariasi. Dalam pasal 7 UUP No. 1 Tahun 1974 pasal 7, syarat mendapat izin perkawinan laki-laki minimal 19 tahun dan perempuan 16 tahun. Kemudian ditegaskan dalam KHI pasal 15 ayat (1). Sedang dalam UU R.I No. 23 Tahun 2002 tentang Perlindungan Anak disebutkan pada pasal 1 ayat (1): "Anak adalah seseorang yang belum berusia 18 tahun. termasuk anak yang masih dalam kandungan dan Undang-undang R.I No. 13 Tahun 2003 tentang Ketenagakerjaan pasal 26: Anak adalah setiap orang yang berumur dibawah 18 (delapan belas) tahun. Sedang yang dimaksud dengan anak dalam Undang-undang R.I No. 4 Tahun 1979 tentang Kesejahteraan Anak pasal 2 disebutkan: Anak adalah seseorang yang belum mencapai umur 21 (dua puluh satu) tahun dan belum pernah kawin Demikian juga dalam Undang-undang Kependudukan bahwa untuk memperoleh Kartu Tanda Penduduk (KTP) harus telah mencapai usia 17 tahun dan Undangundang Pemilu bahwa peserta Pemilu ialah mereka yang telah mencapai usia 17 tahun atau telah menikah, Undang-undang Kewarganegaraan R.I pasal 9 (poin b) menyebutkan bahwa untuk menjadi warga Negara R.I telah mencapai usia 18 tahun atau telah menikah. Lihat Republik Indonesia, "Undang-undang R.I No. 12 Tahun 2006 tentang Kewarganegaraan". 
Pernikahan usia anak adalah hal dilematis. Kasus demikian jarang atau sangat sedikit muncul ke permukaan, tetapi sesungguhnya di penjuru daerah Indonesia banyak terjadi kasus pernikahan usia anak yang pada umumnya dikarenakan pengaruh hukum adat yang masih sangat kental. Di Kabupaten Ponorogo Jawa Timur, data menunjukkan peningkatan angka perkawinan pada usia anak dibandingkan dengan tahun sebelumnya. Hal ini berdasarkan tingginya permintaan surat dispensasi perkawinan usia anak yang diajukan ke Pengadilan Agama Ponorogo. Berdasarkan data Pengadilan Agama Ponorogo, sepanjang tahun 2007 rata-rata 15 hingga 19 surat dispensasi telah diajukan setiap bulan. Sebelumnya rata-rata hanya satu hingga tiga surat setiap bulan. Pernikahan usia anak meningkat $75 \%{ }^{6}$

Pernikahan usia anak ini menimbulkan masalah hukum. Di antaranya terjadi peningkatan angka perceraian akibat nikah di bawah umur sangat tinggi, khususnya di daerah Jawa. Pada tahun 2005 di Semarang tercatat sebanyak 104 kasus dan Surabaya 128 kasus. $^{7}$

Hal tersebut merupakan tantangan besar terhadap legislasi hukum perkawinan di Indonesia, karenabanyak terjadi pelanggaran terhadap undang-undang perkawinan tanpa dapat ditegakkan secara hukum. Pelanggaran yang ada tidak hanya masalah pernikahan usia anak, tetapi pelanggaran juga

\footnotetext{
${ }^{6}$ Lihat Misnan Maulana, "Perkawinan di Bawah Umur meningkat di Ponorogo." Tempo online, 06 September 2007. http://www.tempointeraktif.com. diakses 19 Mei 2012. Pernikahan Syekh Puji dan Ulfa hanyalah salah satu kasus yang muncul kepermukaan karena terekspos oleh media. Namun ribuan kasus lainnya mengendap tanpa penegakan hukum (law enforcement) yang tegas. Hal ini kemudian membuka ruang kontroversi bahwa perkara nikah pada usia anak ternyata disikapi secara berbeda oleh hukum adat, hukum Islam (baca: fikih), serta hukum nasional, bahkan oleh hukum internasional. Tak ketinggalan para pakar hukum, tokoh agama, cendekiawan, sampai masyarakat awam pun ikut memberikan pendapat, baik pendapat yang pro maupun yang kontra terhadap pernikahan usia anak.

7"Jurisdiksi Mahkamah Syar'iyah Propinsi/Pengadilan Tinggi Agama Seluruh Indonesia Tahun 2005", Bahs|ul Masa'il Rakernas Muslimat NU di Makassar pada tanggal 31 Mei 2009.
}

terjadi pada kasus pernikahan poligami, pernikahan di bawah tangan, perceraian di bawah tangan, pelanggaran hak-hak mantan istri, mantan suami atau pun anak-anak dalam perceraian, dan lain-lain.

Memperhatikan realitas yang ada, tuntutan ke arah mengamandemen undang-undang perkawinan pun bergulir. Mulai dengan pemberian sanksi yang tegas terhadap pelanggar ketentuan (khususnya usia kawin) sampai kepada perubahan batas minimal usia perkawinan sebagaimana tercantum dalam aturan perundang-undangan yang dianggap tidak relevan dengan kondisi masyarakat Indonesia. Hal demikianlah yang mendorong penulis untuk mengkaji kebijakan pemerintah terkait dengan batas usia perkawinan anak dalam hukum nasional Indonesia perspektif fikih.

Berdasarkan latar belakang tersebut, maka permasalahan yang akan dikaji adalah sebagai berikut: 1) Bagaimana konsep dasar batas usia perkawinan anak dalam perspektif fikih?; 2) Bagaimana konsep dasar batas usia perkawinan anak dalam perspektif hukum nasional?; 3) Bagaimana upaya rekonstruksi batas usia perkawinan anak dalam hukum nasional Indonesia perspektif fikih?

\section{Batas Usia Perkawinan Anak dalam Pers- pektif Fikih}

Batas usia perkawinan menurut pandangan ulama klasik bervariasi. Kebolehan menikahkan anak usia 6 tahun (belum balig) berdasarkan dalil hadis dari Aisyah yang diriwayatkan oleh Muslim:

"Dari Aisyah bahwasanya Nabi menikahinya dalam usia enam tahun tetapi menggaulinya dalam usia sembilan tahun".

Hadis tersebut menjelaskan bahwa Sayyidah Aisyah menikah dengan Rasul pada usia 6 tahun dan tinggal serumah dengan Rasulullahsaw. padausia 9 tahun. Olehulama klasik, hadis ini dipahami secara tekstual, sehingga menurut mereka, akad bagi anak usia 6 tahun atau lebih adalah sah. Karena 
secara fisik, pertumbuhan anak tersebut sudah tergolong dewasa. Namun pernikahan tersebut baru sebatas akad saja dan anak perempuan itu belum digauli (berkumpul). Namun, apabila hadis ini dipahami secara kontekstual, hadis tersebut hanya sebagai berita (khabar) dan bukan doktrin (khit\}ab) yang harus dilaksanakan atau ditinggalkan, karena boleh jadi alam negeri Hijaz pada masa Rasulullah saw., memungkinkan usia sembilan tahun atau bahkan di bawahnya sudah tergolong dewasa. ${ }^{8}$ Sebagai khabar atau isyarat, maka hadis tersebut bukan perintah untuk melaksanakan perkawinan pada usia 6 tahun sebagaimana usia Aisyah dinikahi oleh Rasulullah saw.

Pemahaman istilah balig relatif berdasarkan kondisi sosial budaya dan kultur, sehingga ketentuan dewasa memasuki usia perkawinan oleh para ulama mazhab itu terakumulasi dalam empat pendapat, baik yang ditentukan dengan umur, maupun dengan tanda-tanda, yakni sebagai berikut: Pertama, Ulama Syafiiyah dan Hanabilah menentukan bahwa masa dewasa itu mulaiumur 15 tahun, walaupun mereka dapat menerima kedewasaan dengan tanda-tanda datang haid bagi perempuan dan mimpi bagi anak laki-laki. Akan tetapi tanda-tanda tersebut tidak sama datangnya pada setiap orang, sehingga kedewasaan ditentukan dengan standar umur. Kedewasaan antara laki-laki dan perempuan sama, karena kedewasaan ditentukan dengan akal. Dengan akal terjadi taklif dan dengan akal pula adanya hukum. Kedua, Abu Hanifah berpendapat bahwa kedewasaan itu datangnya mulai umur 19 tahun bagi laki-laki dan 17 tahun bagi perempuan. Ketiga, Imam Malik menetapkan usia dewasa adalah 18 tahun baik bagi lakilaki maupun perempuan. ${ }^{9}$ Keempat, Mazhab Ja'fari berpendapat bahwa seseorang telah dipandangdewasadandapatmelangsungkan

${ }^{8}$ Lihat Sabri Samin, "Eklektisisme Hukum Islam di Indonesia dalam Memaknai Ruang Privat dan Ruang Publik", (Makalah yang disajikan pada Seminar Hukum Islam di STAIN Menado, 13 April 2009), h. 12.

${ }^{9}$ Lihat Abdul Qadir Audah, Al-Tasyri' al-Jinai alIslami, Juz I (Kairo: Dar al-Urubah, 1964), h. 602-603. perkawinan jika telah berumur 15 tahun bagi laki-laki dan 9 tahun bagi perempuan. Mazhab Ja'fari juga memandang bahwa seorang wali boleh mengawinkan anak yang masih di bawah umur. ${ }^{10}$ Dari pendapat tersebut, pendapat Abu Hanifah yang tergolong tinggi memberikan batas usia. Pendapat ini pula yang menjadi rujukan perundang-undangan di Indonesia.

Hal ini tampak bahwa masalah perkawinan di samping termasuk dalam wilayah ibadah (ubudiyah), juga merupakan urusan hubungan antar manusia (mu'amalah) yang oleh agama hanya diatur dalam bentuk prinsip-prinsip umum (universal). Oleh karena itu, kedewasaan untuk menikah sebaiknya dipahami sebagai masalah ijtihadiyah, sehingga perlu melakukan interpretasi lebih lanjut terhadap persoalan-persoalan yang berkaitan dengan batas usia perkawinan, sesuai kondisi dimana dan kapan aturan tersebut ditetapkan.

Sudut pandang yang berbeda mengenai batas usia perkawinan, disebabkan oleh pemahaman teks nas, baik Alquran maupun hadis, serta pemahaman secara kontekstual berdasarkan sudut pandang budaya, kultur, kesehatan, psikologis dan sebagainya. Ulama fikih klasik mensyaratkan seseorang yang akan menikah telah balig. Indikator balig yang digunakan adalah kematangan fisik yakni menstruasi bagi anak perempuan dan mimpi basah bagi anak laki-laki. Walaupun para ulama klasik juga memberikan batasan berdasarkan umur. Namun, orang tua/wali diberi hak untuk menikahkan anak yang belum balig. Sedang ulama kontemporer memahami nas secara kontekstual, sehingga perlu adanya terobosan dan perubahan memandang persoalan tersebut dari berbagai aspek yakni aspek kesehatan, aspek psikologis dan aspek budaya. Ulama kontemporer beranggapan bahwa kelompok klasik/tradisional menafsirkan ayat-ayat dalam Alquran dan juga praktik Rasulullah

${ }^{10}$ Lihat Muhammad Jawad Mughniyah, Fikih Lima Mazhab, alih bahasa Masykur AB (Cet. IV; Jakarta: Lentera, 1999), h. 316-318. 
saw. saat dirinya menikahi Siti Aisyah r.a yang masih berusia 6 tahun secara tekstual. Oleh sebab itulah, kelompok tradisional memperkenankan perkawinan anak dibawah umur dengan berdasarkan pemahaman yang kaku dan rigid. Padahal, hadis tersebut dapat dipahami kebolehan secara khusus (lex spesialis) dan bukan kebolehan secara umum (lex generalis).

Beberapa pendapat para mufasir tentang sampainya waktu menikah (bulug al-nikah) dalam QSal-Nisa'/4 ayat6juga bervariasi. Ada yang berpendapat bahwa ukuran sampainya waktu nikah ditandai dengan kematangan fisik dan ada pula yang berpendapat bukan kematangan fisik tetapi kematangan secara psikis. Karena seseorang yang telah dewasa fisik belum dijamin dewasa secara psikis. Artinya, ia telah cakap dan mampu memikul tanggung jawab.

Ibnu Katsier berpendapat, sampainya waktu nikah adalah cukup umur atau cerdas. Adapun yang dimaksud dengan balig adalah dengan adanya mimpi yaitu bermimpi dalam tidurnya yang menyebabkan keluar air yang memancar, dengan air itu terjadinya anak. ${ }^{11}$

Pendapat Ibnu Katsier tentang sampainya waktu umur untuk menikah, tidak berpatokan pada balig saja, tetapi pada umur atau kecerdasan (rusyd).

Rasyid Ridha mengatakan bahwa bulug al-nikah berarti sampainya seseorang kepada umur untuk menikah, yakni sampai bermimpi. Pada usia ini, seseorang telah dapat melahirkan anak dan menurunkan keturunan, sehingga tergerak hatinya untuk menikah. Pada usia ini, seseorang telah dibebankan hukum-hukum agama, baik ibadah maupun muamalah serta hudud. Oleh karena itu makna rusyd adalah kepantasan seseorang untuk melakukan tas\{arruf yang mendatangkan kebaikan dan menjauhi kejahatan. Hal ini merupakan bukti kesempurnaan akalnya. ${ }^{12}$

${ }^{11}$ Tafsir Ibnu Katsier, Juz IV (Mesir: Dar al-Kutub, t.th), h. 453.

${ }^{12}$ Muhammad Rasyid Ridha, Tafsir al-Manar, Juz I (Mesir: Al-Manar, 2000 M/1460 H), h. 396-397.
Pada dasarnya Rasyid Ridha sependapat dengan Ibnu Katsier, yakni penekanan pada kata rusyd. Namun tetap mengatakan bahwa sampainya seseorang kepada umur untuk menikah, melalui ciri-ciri fisik, yakni sampai bermimpi dan menstruasi.

Sedangkan Hamka berpendapat bulug alnikah diartikan dengan dewasa. Kedewasaan itu bukanlah bergantung pada umur, tetapi bergantung kepada kecerdasan atau kedewasaan pikiran. Karena ada juga anak yang usianya belum dewasa, tetapi ia telah cerdik dan ada pula orang yang usianya telah dewasa, tetapi pemikirannya belum matang. ${ }^{13}$

Penafsiran Hamka ini lebih moderat, bahwa batasan umur menjadi relatif sifatnya, disebabkan setiap anak pasti berbeda. Oleh karena itu, kecerdasan atau kedewasaan pikiran menjadi patokan utama sampainya waktu menikah.

Beberapa pendapat dalam penafisiran itu, menurut Zaki disebabkan perbedaan sudut pandang. Ibnu Katsier menitikberatkan pada segi fisik lahiriah dan sekaligus telah mukalaf. Sedang Rasyid Ridha dan Hamka menitikberatkan pada segi mental, yakni dilihat pada sikap dan tingkah laku seseorang. ${ }^{14}$

Penafsiran-penafsiran tersebut, menunjukkan adanya perbedaan ide antara ulama kontemporer dan ulama klasik dalam merespons kebolehan seseorang untuk menikah. Pendapat lain yang digawang Ibnu Syubromah menyatakan bahwa agama melarang pernikahan dini (pernikahan sebelum usia balig). Menurutnya, nilai esensial pernikahan adalah memenuhi kebutuhan biologis dan melanggengkan keturunan. Sementara dua hal ini tidak terdapat pada anak yang belum balig. Ia lebih menekankan pada tujuan pokok pernikahan. Ibnu Syubrumah mencoba melepaskan diri dari kungkungan

\footnotetext{
${ }^{13}$ Hamka, Tafsir al-Azhar, Juz IV (Jakarta: Pustaka Panji Masyarakat, 1984), h. 267.

${ }^{14}$ Lihat Zaki Fuad Khalil. "Tinjauan Batas Minimal Usia Kawin; Studi Perbandingan Antara Kitab-kitab Fikih dan UU Perkawinan di Negara-negara Muslim," Mimbar Hukum VII, No. 26, (1996), h. 70.
} 
teks. Memahami masalah ini dari aspek historis, sosiologis, dan kultural yang ada. Dalam menyikapi pernikahan Nabi saw. dengan Aisyah (yang saat itu berusia usia 6 tahun), Ibnu Syubromah menganggap sebagai ketentuan khusus bagi Nabi saw. yang tidak bisa ditiru oleh umatnya. ${ }^{15}$

Pendapat ulama kontemporer ini, lebih konstruktif melihat sampainya waktu menikah tidak hanya pada ciri-ciri fisik (balig), tetapi penekanannya pada kesempurnaan akal dan jiwa (rusyd), dengan melihat persoalan batas usia perkawinan dari berbagai sudut pandang. Dengan demikian, perkawinan tidak hanya membutuhkan kematangan fisik (biologis), tetapi kematangan psikologis, sosial, agama, bahkan kematangan intelektual. Kematangan usia dalam pernikahan, idealnya merupakan akumulasi dari semua aspek, sehingga seseorang dianggap siap untuk hidup berumah tangga.

Persoalan usia menikah merupakan persoalan fikih, namun fikih sangat terikat dengan kondisi sosial dan budaya suatu masyarakat di mana fikih itu diberlakukan. Dalam konteks kehidupan berbangsa dan bernegara, maka fikih yang di maksud adalah undang-undang, sepanjang hal itu telah diatur atau dikukuhkan oleh negara. Di sini, fikih yang telah dikukuhkan oleh negara tersebut, meniadakan keberlakuan fikihfikih lain sekaligus bersifat mengikat bagi semua warga negara. Bahkan regulasi ini dapat dianggap sebagai fikih munakahat bagi masyarakat Indonesia. Oleh karena itu, setiap perbuatan yang didasarkan pada fikih-fikih tertentu yang berbanding terbalik dengan ketentuan undang-undang negara, maka dalam perspektif syariat Islam, perbuatan itu bisa dianggap sebagai pelanggaran hukum negara. Hal ini menunjukkan bahwa kitab-kitab fikih klasik sesuai dan relevan pada masanya, sedang untuk masa sekarang harus dilakukan pengkajian ulang terhadap

\footnotetext{
${ }^{15}$ Lihat Yusuf Fatawie, "Pernikahan Dini dalam Perspektif Agama dan Negara", http//.www. PesantrenVirtual. com. diakses 19 Mei 2012.
}

materi hukumnya dalam rangka usaha pembaruan hukum Islam, terutama dalam mengantisipasi perkembangan era modern.

\section{Batas Usia Perkawinan Anak dalam Perspektif Hukum Nasional}

Dalam perundangan-undangan, konsep anak atau seseorang dikatakan dewasa, sehingga mampu bertanggung jawab sangat bervariasi. Undang-undang R.I No. 23 Tahun 2002 tentang Perlindungan Anak disebutkan pada pasal 1 ayat (1) :

"Anak adalah seseorang yang belum berusia 18 tahun. termasuk anak yang masih dalam kandungan". ${ }^{16}$

Apabila merujuk pada peraturan perundang-undangan ini, maka seseorang yang masih berusia di bawah 18 tahun adalah tergolong usia anak serta berhak diberi perlindungan atas hak-hak yang mesti didapatkannya.

Usia anak juga disebutkan dalam UndangUndang R. I No. 3 Tahun 1997 tentang Pengadilan Anak, pasal 1 ayat (1):

"Anak adalah orang yang dalam perkara Anak Nakal telah mencapai umur 8 (delapan) tahun tetapi belum mencapai umur 18 (delapan belas) tahun dan belum pernah kawin". ${ }^{17}$

Pada pasal 4 ayat (1) disebutkan:

"Batas umur Anak Nakal yang dapat diajukan ke Sidang Anak adalah sekurangkurangnya 8 (delapan) tahun tetapi belum mencapai umur 18 (delapan belas) tahun dan belum pernah kawin". ${ }^{18}$

Usia anak sebagaimana yang disebutkan dalam Undang-undang R.I No. 13 Tahun 2003 tentang Ketenagakerjaan pada pasal 26: "Anak adalah setiap orang yang berumur

${ }^{16}$ Republik Indonesia, Undang-undang R.I No. 23 Tahun 2002 tentang Perlindungan Anak," dalam Syaifullah (Penyusun) Undang-undang Rumah Tangga No. 23 Tahun 2004 \& Undang-undang Perlindungan Anak No. 23 Tahun 2002 (Cet. I; Padang: Baduose Media, 2008), h. 42.

${ }^{17}$ Republik Indonesia, “Undang-Undang R. I No. 3 Tahun 1997 tentang Pengadilan Anak", http://www. google.co.id. diakses 19 Mei 2012 .

.lbid $\quad 1 \wedge$ 
dibawah 18 (delapan belas) tahun". ${ }^{19}$ Sedang yang dimaksud dengan anak dalam Undangundang R.I No. 4 Tahun 1979 tentang Kesejahteraan Anak pasal 2 disebutkan: Anak adalah seseorang yang belum mencapai umur 21 (dua puluh satu) tahun dan belum pernah kawin. ${ }^{20}$

Ketetapan batas usia anak yang terdapat dalam regulasi atau aturan perundangundangan tersebut bervariasi. Demikian pula batas usia berkaitan dengan hak-hak yang diberikan kepada seseorang, ketika ia dianggap mampu atau cakap untuk bertindak di dalam hukum juga bervariasi.

Dalam Undang-undang R.I No. 1 Tahun 1974 tentang Perkawinan, disebutkan pada pasal 7 (ayat 1): "Syarat mendapat izin perkawinan laki-laki minimal 19 tahun dan perempuan 16 tahun." 21

Adapun penjelasan pasal itu yakni untuk menjaga kesehatan suami istri dan keturunan, perlu ditetapkan batas-batas umur untuk perkawinan. ${ }^{22}$ Dalam Kompilasi Hukum Islam, ketentuan tersebut semakin ditegaskan, sebagaimana dinyatakan pada pasal 15 ayat (1) sebagi berikut:

Untuk kemaslahatan keluarga dan rumah tangga, perkawinan hanya boleh dilakukan calon mempelai yang telah mencapai umur yang ditetapkan dalam pasal 7 Undangundang R.I No. 1 Tahun 1974 yakni calon suami sekurang-kurangnya berumur 19 tahun dan calon istri sekurang-kurangnya berumur 16 tahun. $^{23}$

Bahkan di dalam Peraturan Pemerintah R.I No. 9 Tahun 1975 tentang Pelaksanaan Hukum Perkawinan diatur ulang. Bagi pasangan yang ingin menikah di bawah usia

\footnotetext{
${ }^{19}$ Republik Indonesia, "Undang-Undang R.I No. 13 Tahun 2003 tentang Ketenagakerjaan", http://www. google.co.id. diakses 19 Mei 2012 .

${ }^{20}$ Republik Indonesia, “Undang-Undang R.I No. 4 Tahun 1979 tentang Kesejahteraan Anak. http://www. google.co.id. (14 Mei 2012).

${ }^{21}$ Republik Indonesia, “Undang-undang R.I. No. 1 Tahun 1974 tentang Perkawinan" (Cet. II; Surabaya: Pustaka Tinta Mas, 1990), h. 9.

${ }^{22}$ Ibid., h. 29.

${ }^{23}$ Republik Indonesia, Kompilasi Hukum Islam (Surabaya: Karya Anda, t.th.), h. 24-25.
}

yang telah ditetapkan diperbolehkan, dengan syarat mendapatkan dispensasi nikah dari Pengadilan Agama. Hal ini berarti memberi peluang bagi seseorang untuk melakukan pernikahan pada usia anak-anak.

Sedangkan dalam Undang-undang R.I No. 23 Tahun 2006 tentang Administrasi Kependudukan disebutkan dalam pasal 63 ayat (1 dan 2) bahwa:

(1) Penduduk Warga Negara Indonesia dan Orang Asing yang memiliki Izin Tinggal Tetap yang telah berumur 17 (tujuh belas) tahun atau telah kawin atau pernah kawin wajib memiliki KTP.

(2) Orang Asing yang mengikuti status orang tuanya yang memiliki Izin Tinggal Tetap dan sudah berumur 17 (tujuh belas) tahun wajib memiliki KTP. ${ }^{24}$

Aturan ini juga memberi peluang kepada seseorang yang masih tergolong usia anak, khususnya anak yang masih di bawah usia 18 tahun, karena alasan telah kawin untuk memperoleh Kartu Tanda Penduduk (KTP). Di samping memperoleh pengakuan sebagai penduduk setempat, dengan kartu tersebut seorang anak dapat melakukan tindakan hukum lainnya, seperti hak yang diberikan kepada orang dewasa pada umumnya. Misalnya mendapatkan hak pilih dalam Pemilu. Sebagaimana disebutkan pula dalam Undang-undang R.I No. 22 Tahun 2007 tentang Penyelenggaraan Pemilu dalam Ketentuan Umum pasal 1 ayat 22 bahwa:

"Pemilih adalah warga Negara Indonesia yang telah genap berumur 17 (tujuh belas) tahun atau lebih atau sudah/pernah kawin". ${ }^{25}$

Antara Undang-undang kependudukan dan pemilu itu, sama-sama menyebutkan usia 17 tahun seseorang sudah diberi hak, tetapi tidak sesuai dengan usia anak seperti yang disebutkan dalam Undang-undang R.I

\footnotetext{
${ }^{24}$ Republik Indonesia, Undang-undang R.I No. 23 Tahun 2006 tentang Administrasi Kependudukan, http://www.google.co.id. diakses 19 Mei 2012 .

${ }^{25}$ Republik Indonesia, Undang-undang R.I No. 22 Tahun 2007 tentang Penyelenggaraan Pemilu, http:// www.gagasmedia.com. diakses 19 Mei 2012 .
} 
No. 23 Tahun 2002 tentang Perlindungan Anak.

Lain halnya dengan Undang-undang R.I No.12Tahun 2006 tentang Kewarganegaraan. Pada pasal 9 (poin b) menyebutkan bahwa:

"Untuk menjadi warga Negara R.I telah mencapai usia 18 tahun atau telah menikah" ${ }^{26}$

Namun demikian, pasal ini memberi peluang kepada anak yang belum berusia 18 tahun tetapi alasan telah menikah. Hal ini berarti memberi peluang nikah pada usia anak. Pemberian hak kewarganegaraan pada pasal tersebut telah sesuai dengan standar usia anak dalam Undang-undang R.I No. 23 Tahun 2002 tentang Perlindungan Anak, yakni 18 tahun. Tetapi pada satu sisi pasal ini menolerir seseorang yang berusia di bawah 18 tahun tetapi sudah menikah. Logikanya, seseorang yang masih tergolong usia anak, namun telah menikah walaupun hanya sehari, maka orang tersebut digolongkan sebagai orang yang telah mampu untuk diberi hak sebagaimana disebutkan dalam perundangundangan. Artinya, aturan tersebut jelas membuka peluang perkawinan pada usia anak. Aturan ini didukung dengan adanya pemberian izin dispensasi kawin bagi yang yang akan menikah dibawah usia yang telah ditetapkan sebagaimana yang tercantum pada pasal 7 ayat (2) dan pasal 15 ayat (2).

Usia yang bervariasi ini menurut hemat penulis adalah inkonsisitensi terhadap usia dewasa dalam aturan perundang-undangan di Indonesia. Hal ini akan berdampak pada sulitnya masyarakat mendapatkan kepastian hukum yang mereka kehendaki. Kepastian hukum menurut Van Apeldoorn sebagaimana dikutip oleh Peter Mahmud, dapat ditentukan hukum apa yang berlaku untuk masalah-masalah yang kongkrit. Dengan demikian, pihak-pihak yang berperkara sudah dapat mengetahui sejak awal ketentuan apa yang digunakan apabila

${ }^{26}$ Republik Indonesia, Undang-undang R.I No. 12 Tahun 2006 tentang Kewarganegaraan, dalam Lian Nury Sanusi (Penyunting) Undang-undang R.I No. 12 Tahun 2006 tentang Kewarganegaraan (Cet. I; Jakarta: Kawan Pustaka, 2006), h. 5. terjadi sengketa. ${ }^{27}$

Implikasinya pada masalah batas usia anak dalam hukum perkawinan bagi anak perempuan yakni usia 16 tahun, apakah mengacu pada Undang-undang Perkawinan dan Kompilasi Hukum Islam atau usia anak yakni 18 tahun dalam Undang-undang Perlindungan Anak. Terkait standar usia dewasa atau cakap hukum dalam regulasi itu perlu adanya penyeragaman untuk menghindari konsep yang berbeda-beda tentang anak.

Batas usia yang digunakan dalam Undang-undang R.I No. 1 Tahun 1974 tentang Perkawinan, jelas bertentangan dengan Undang-undang R.I No. 23 Tahun 2002 tentang Perlindungan Anak dan Konvensi Hak Anak (1990) yang diratifikasi melalui Kepres R.I Tahun 2000 mengenai Hak Anak yang isinya menegaskan batas usia anak adalah 18 tahun. Dengan demikian, tuntutan perubahan standar usia perkawinan dalam undang-undang perkawinan, hendaknya di respon positif oleh para penentu kebijakan. Sebagai produk hukum, UUP perlu dikaji ulang setelah 34 tahun diberlakukan. Perlu dilakukan evaluasi, sejauhmana efektifitasnya dalam mengatur perilaku masyarakat dalam perkawinan dan bagaimana respon masyarakat terhadap UUP, apakah masih relevan untuk digunakan saat ini. Diharapkan aturan hukum yang ditetapkan, dapat dipatuhi oleh masyarakat, dengan menitikberatkan pada aspek maslahah (manfaat) yang menjadi tujuan ditetapkannya aturan tersebut.

Terkait usia perkawinan dalam Kompilasi Hukum Islam, ketentuan tersebut semakin menegaskan ketentuan yang terdapat dalam Undang-undang R.I No. 1 Tahun 1974 tentang Perkawinan. Oleh karena itu, pemberlakuan KHI selama 18 tahun, perlu dilakukan evaluasi, untuk melihat sejauhmana efektifitas pelaksanaanya di masyarakat dan respon masyarakat terhadap KHI, apakah masih relevan untuk

\footnotetext{
${ }^{27}$ Van Apeldoorn dalam Peter Mahmud Marzuki, Penelitian Hukum (Cet. V; Jakarta: Kencana, 2009), h. 59-61.
} 
digunakan saat ini. Dengan demikian, KHI akan dapat mengakomodir kebutuhan hukum masyarakat, khususnya umat Islam. Penggabungan beberapa mazhab ini (intradoktrinal reform) dalam pembentukan hukum Islam Indonesia, merupakan salah satu sistem guna mencapai tujuan pembaruan hukum Islam, yakni menjawab tantangan dan keperluan masyarakat Indonesia menuju kemaslahatan dan mencegah kemudaratan (jalb al-mashalih wa dar al-mafasid).

\section{Upaya Rekonstruksi Batas Usia Perkawinan Anak dalam Hukum Nasional Indonesia Perspektif Fikih}

Masalah kedewasaan menurut Helmi Karim merupakan masalah yang penting, khususnya dalam lembaga perkawinan. Karena membawa pengaruh terhadap keberhasilan rumah tangga. Orang yang telah dewasa, fisik dan mental, belum bisa membina dan mendirikan rumah tangga yang sempurna, terutama apalagi orang muda yang belum dewasa. ${ }^{28}$ Tanpa kedewasaan, persoalanpersoalan yang muncul dalam rumah tangga akan disikapi dengan emosi. Kunci perkawinan yang sukses, dituntut adanya kedewasaan dan kematangan dari segi fisik, mental dan emosional calon suami maupun istri yang akan atau hendak melangsungkan perkawinan. ${ }^{29}$ Di samping itu, dengan kematangan fisik, mental, dan emosional dari masing-masing mempelai

\footnotetext{
${ }^{28}$ Lihat Helmi Karim, op. cit., 64.

${ }^{29}$ Emosi merupakan sesuatu keadaan yang bergolak dalam diri manusia. Ada dua pendapat proses terjadinya emosi; Pertama, pendapat nativistik mengatakan bahwa pada dasarnya emosi merupakan bawaan sejak lahir. Salah satu penganut teori ini adalah Rene Descartes (1596-1650). Ia mengatakan bahwa sejak lahir manusia mempunyai enam emosi dasar yaitu: cinta, kegembiraan, keinginan, benci, sedih, dan kagum. Kedua, Pendapat yang empiristik mengatakan bahwa emosi dibentuk oleh pengalaman dan proses belajar. Penganut pendapat ini diantaranya William James (1842-1910, Amerika Serikat) dan Carl Lange (Denmark). Menurut mereka emosi adalah hasil persepsi seseorang terhadap perubahan-perubahan yang terjadi pada tubuh sebagai respon terhadap rangsangan-rangsangan yang datang dari luar.. Lebih lanjut lihat Netty Hartati dkk, Islam dan Psikologi, Edisi I (Cet. I: Jakarta: PT. Raja Grafindo Persada, 2004), h. 90, 96 dan 97.
}

akan dapat menghasilkan keturunan yang baik dan juga sehat. Kesemuanya ini bertujuan mewujudkan perkawinan secara baik, dan bukan sebaliknya, perkawinan harus berakhir dengan sebuah perceraian, karena disebabkan ketidakstabilan dan ketidakmatangan jiwa/emosional dan fisik kedua belah pihak, yaitu suami dan istri. Dalam perkawinan ada emosi yang akan menentukan kedewasaan dalam merespon masalah dan ada pula kecerdasan yang menentukan langkah strategis ke depannya mencapai tujuan kemaslahatan hidup di dunia dan akhirat.

Konstruksi hukum perkawinan Indonesia yang berlaku hingga saat ini dianggap tidak relevan. Hal ini menurut penulis, menghendaki rekonstruksi terhadap formulasi hukum karena dianggap tidak sesuai lagi dengan kebutuhan, situasi, dan kondisi yang ada. Perundang-undangan yang mengatur batas minimal usia perkawinan tidak dapat menjelaskan dan menyelesaikan kompleksitas permasalahan hukum yang muncul, terutamanya tingginya angka perkawinan usia anak yang banyak memberi dampak negatif, baik bagi individu maupun masyarakat, dan negara dalam arti luas. Hukum semestinya dipatuhi oleh masyarakat dan mampu menghadapi realitas kehidupan modern, karena masyarakat membutuhkan hukum yang secara aplikatif dapat memberikan manfaat dan mengatur kehidupan sosial masyarakat demi mewujudkan kehidupan yang lebih baik.

Hukum yang bermanfaat adalah hukum yang secara aplikatif telah memenuhi kriteria sebagai undang-undang yang baik. Menurut Erman Radjagukguk, undang-undang yang baik adalah undang-undang yang memenuhi unsur sebagai berikut: (1) norma harus sesuai dengan perasaan masyarakat; (2) isinya merupakan pesan yang dapat dimengertioleh masyarakat; (3) ada aturan implementasi; (4) harus ada sarana pelaksanaannya dan harus sinkron dengan undang-undang lainnya. ${ }^{30}$

\footnotetext{
${ }^{30}$ Lihat Erman Radjagukguk dalam Yuliandri, Asas-
} asas Pembentukan Peraturan Perundang-undangan yang 
Oleh karena itu, menurut hemat penulis bahwa upaya rekonstruksi dalam membedah batas usia perkawinan mencakup beberapa hal:

Pertama, perlu penyeragaman usia anak dalam perundang-undangan. Apabila usia anak tetap mengacu pada UU R.I No. 23 Tahun 2002 tentang Perlindungan Anak yakni usia 18 tahun, maka batas usia minimal 16 tahun bagi perempuan dan 19 tahun bagi laki-laki untuk menikah dalam UUP dan KHI dinaikkan menjadi 19 tahun bagi perempuan dan 21 tahun bagi laki-laki. Penetapan usia ini, agar tidak bertentangan dengan Undangundang Perlindungan Anak dan juga perundang-undangan lainnya. Pada usia tersebut, khususnya anak perempuan telah menyelesaikan jenjang pendidikan SLTA. Selain itu, dengan mempertimbangkan aspek kematangan biologis, psikologis, dan sosial budaya. Sedangkan bagi baik laki-laki, usia 21 tahun telah memenuhi syarat untuk memikul tanggung jawab dan mampu (rusyd) menjadi pemimpin keluarga. Walaupun usia tersebut belum dapat dikatakan ideal, namun usia 21 dan 19 dinilai sudah masuk dalam kelayakan secara fisik dan psikologis. Dalam hal fisik, wanita usia 19 tahun sudah mampu untuk melakukan reproduksi. Selain itu, pada usia 19 tahun kedewasaan berfikir sudah dimiliki. Demikian pula bagi laki-laki.

Kedua, Pemberian izin dispensasi dengan syarat yang ketat dan sebaiknya diberi batas usia minimal dispensasi yakni usia 16 tahun bagi perempuan dan 19 tahun bagi laki-laki. Pertimbangan pada usia 16 tahun, anak perempuan telah mengikuti program wajib belajar sampai usia 15 tahun (lulus SMP). ${ }^{31}$ Sedangkan pemberian izin dispensasi bagi laki-laki pada usia 19 tahun, berarti telah lulus SMU dan sudah dapat mencari nafkah.

Baik, Edisi I (Cet. I; Jakarta: RajaGrafindo Persada, 2009), h. 136.

${ }^{31}$ Sebagaimana yang tercantum pada pasal 6: "Setiap warga negara yang berusia tujuh sampai dengan lima belas tahun wajib mengikuti pendidikan dasar" Lihat Republik Indonesia, Undang-undang R.I No. 20 Tahun 2003 tentang Sistem Pendidikan Nasional (Cet. I; Jakarta: Biro Hukum dan Organisasi Sekretariat Jenderal Departemen Pendidikan Nasioanl, 2003), h. 13.
Pemberian syarat yang ketat bertujuan untuk menghindari ketergantungan perempuan secara ekonomi. Perkawinan usia anak dalam perspektif gender, merupakan bentuk ketidakadilan gender yang dialami wanita akibat kuat berakarnya budaya patriarki pada masyarakat yang menganggap wanita sebagai barang dan selalu berada di bawah subordinasi. Perempuan sebagai pencari nafkah tambahan, tidak perlu mengenyam pendidikan tinggi. Perkawinan usia anak berarti menguatkan superioritas laki-laki terhadap inferioritas perempuan. Jelas bertentangan dengan kehidupan keluarga yang menuntut adanya peran dan tanggung jawab bersama, baik bagi laki-laki maupun perempuan.

Penulis menilai, pertimbangan maslahah dan mudarat sifatnya relatif. Kondisi negara Republik Indonesia menghendaki adanya peraturan yang lebih tegas. Meninggalkan kemaslahatan yang lebih besar demi untuk mengejar kemaslahatan yang lebih kecil dan sengaja menghindari kemudaratan yang lebih ringan, walaupun terancam oleh kemudaratan yang justru lebih berat, hendaknya dipertimbangkan dengan matang. Memaralelkan antara nilai ibadah dan nilai muamalah dalam perkawinan usia anak adalah tepat dan ideal. Sebagai contoh, pada satu sisi ada anak yang masih berkeinginan besar untuk melanjutkan pendidikan, tetapi oleh orang tua dipaksa untuk menikah dengan alasan ekonomi atau alasan lainnya, maka menikahkan anak itu bisa memberi $m u$ dharat atau sebaliknya, menolak perkawinan tersebut memberikan maslahah kepada anak. Namun pada sisi lain, ada anak yang memiliki kecenderungan (libido) seksual yang tinggi dan pergaulan bebas, maka menikahkan anak tersebut membawa maslahah, dan apabila anak tersebut tidak segera dinikahkan akan membawa mudharat baik pada anak maupun keluarga. Berdasarkan kaidah usul (dar almafasid awla min jalb al-masalih).

Pendewasaan Usia Perkawinan (PUP) yang diprogramkan oleh pemerintah dan juga usaha-usaha menolak pernikahan pada 
usia anak yang dilakukan oleh sejumlah organisasi perlindungan anak hanya akan menjadi wacana perdebatan tak berujung. Solusi yang harus dilakukan oleh negara dalam melindungi anak dari praktik-praktik pernikahan usia anak adalah dengan merevisi UU R.I No. 1 Tahun 1974 tentang Perkawinan dan KHI. Dukungan ini juga datang dari Komisi Nasional Anti Kekerasan Terhadap Perempuan (Komnas Perempuan) bersama-sama sejumlah organisasi gerakan perempuan pernah mengajukan revisi terhadap UU Perkawinan. Beberapa permasalahan pokok yang diusulkan agar direvisi antara lain; Pendewasaan Usia Perkawinan di atas 18 tahun, dengan tidak membedakan batas minimal usia perkawinan bagi perempuan dan laki-laki. ${ }^{32}$

Selain itu, berdasarkan Deklarasi Wina, Komite CEDAW (Convention on the Elimination of All Forms of Discrimination Against Women) mempertimbangkan bahwa usia minimum untuk perkawinan adalah 18 tahun untuk laki-laki dan perempuan. Sedang usulan sekurang-kurangnya 19 tahun tanpa pembedaan usia atas dasar jenis kelamin merupakan implementasi dari berbagai UU nasional yang ada, khususnya UU Perlindungan anak yang menetapkan batas usia anak-anak adalah 18 tahun (Pasal 1 Angka 1 UU R.I No. 23 Tahun 2002). Demikian juga ketentuan internasional seperti dalam Konvensi Hak Anak yang diratifikasi pemerintah pada tahun 1990 dalam Kepres Tahun 2000 tentang Hak Anak. ${ }^{33}$

Perbedaan usia sebagaimana tuntutan

${ }^{32}$ Lihat Ahmad Sofian dan Misran Lubis, "PernikahanDinidanTuntutanRevisiUUPerkawinan," Waspada Online, 21 November 2008, http://www. waspada. co. Id. diakses 19 Mei 2012 . Terkait revisi perundang-undangan, Estu Fanani mengatakan dalam Temu Mitra Terre des Hommes Netherlanda 2009: Sinergi Menuju Perubahan Besar. bahwa agenda untuk merevisi Undang-undang Perkawinan ini telah masuk dua kali periode Program Legislasi Nasional (Prolegnas) DPR, tepatnya di tahun periode 1999-2004 dan 2005-2009. Akan tetapi, pada periode 2005-2009 pembahasan Revisi UU Perkawinan tidak mendapat prioritas dan ditempatkan dalam urutan pembahasan No. 192.

${ }^{33}$ Ibid. tersebut, sejalan dengan pendapat Musdah Mulia bahwa perbedaan usia melahirkan subordinat bagi perempuan. ${ }^{34}$ menurut penulis bukan sesuatu yang urgen, karena Rasulullah saw. pun menikah dengan usia yang jauh berbeda dengan Siti Khadijah, yakni 25 tahun dan Khadijah berusia 40 tahun. Perbedaan usia tidak akan menyebabkan superioritas dan inferioaritas yang satu terhadap yang lain, apabila masing-masing telah dewasa dan dapat menghargai serta menyadari hak dan kewajibannya. Di samping itu, secara ilmiah anak perempuan lebih cepat memasuki usia balig, kematangan alatalat reproduksi perempuan lebih cepat dari kematangan alat reproduksi laki-laki. ${ }^{35}$

Terlepas dari perbedaan batas usia lakilaki dan perempuan dalam perkawinan, dukungan dan tuntutan tentang revisi undangundang perkawinan merupakan perwujudan dari upaya bersama untuk menyelamatkan masa depan anak-anak Indonesia, karena pada dasarnya anak hanya titipan dan karunia Tuhan. Prinsip mengedepankan kepentingan terbaik bagi anak dalam setiap pengambilan keputusan yang menyangkut anak merupakan kewajiban semua pihak. Oleh karena itu, merekonstruksi usia perkawinan dalam Undang-undang Perkawinan merupakan langkah kongkrit sebagai upaya menuju penegakan hukum (law enforcement) di Indonesia.

\section{Kesimpulan}

Sebagai penutup dapat dikemukakan beberapa kesimpulan sebagai berikut: pertama, Konsep batasan usia perkawinan anakdalamfikihbervariasi.Dalamkajian fikih klasik, istilah umum yang digunakan adalah

${ }^{34}$ Musdah Mulia, "Menuju Hukum Perkawinan yang Adil: Memberdayakan Perempuan Indonesia", dalam Sulistyowati Irianto, Perempuan dan Hukum; Menuju Hukum yang Berperspektif Kesetaraan dan Keadilan. Cet. I; Jakarta: Yayasan Obor Indonesia, 2006, h. 149

${ }^{35}$ Lihat Aliah B. Purwakania Hasan, Psikologi Perkembangan Islami: Menyingkap rentang Kehidupan Manusia dari Prakelahiran hingga Pascakematian, Edisi I. (Cet. 1; Jakarta: RajaGrafindo Persada, 2006), h. 110111. 
balig (cukup umur) dengan ciri-ciri fisik menstruasi bagi anak perempuan dan mimpi basah bagi anak laki-laki. Adapun pendapat ulamakontemporer, lebih konstruktifmelihat sampainya waktu menikah tidak hanya pada ciri-ciri fisik (balig), tetapi penekanannya pada kesempurnaan akal dan jiwa (rusyd).

Kedua, konsep batasan usia perkawinan dalam hukum nasional disebutkan pada pasal 7 (ayat 1) Undang-undang No.1 Tahun 1974 tentang Perkawinan dan KHI pasal 15 ayat (1) yakni usia 19 tahun bagi laki-laki dan 16 tahun bagi perempuan. Usia ini dianggap rendah, khususnya bagi perempuan dan bertentangan dengan Undang-undang No.23 Tahun 2002 tentang Perlindungan Anak dan Konvensi Hak Anak (1990) yang diratifikasi melalui Kepres Tahun 2000 mengenai Hak Anak yang isinya menegaskan batas usia anak adalah 18 tahun. Konsep ini juga berbeda dengan Undang-Undang No. 3 Tahun 1997 tentang Pengadilan Anak, Undang-undang No. 13 Tahun 2003 tentang Ketenagakerjaan, Undang-undang No. 23 Tahun 2006 tentang Administrasi Kependudukan, Undang-undang No. 22 Tahun 2007 tentang Penyelenggaraan Pemilu,

\section{DAFTAR PUSTAKA}

Audah, Abdul Qadir. Al-Tasyri' al-Jinai alIslami. Kairo: Dar al-Urubah, 1964

Chalil, Zaki Fuad, "Tinjauan Batas Minimal Usia Kawin; Studi Perbandingan Antara Kitab-Kitab Fikih dan UndangUndang Perkawinan di Negara-Negara Muslim," Mimbar Hukum VII, no. 26, Tahun 1996

Fatawie, Yusuf, "Pernikahan Dini dalam Perspektif Agama dan Negara", http:// www. PesantrenVirtual.com diakses 19 Mei 2012.

Hamka.Tafsir al-Azhar. Jakarta: Pustaka Panji Masyarakat, 1984

Hartati, Netty dkk. Islam dan Psikologi. Jakarta: PT. Raja Grafindo Persada, 2004

Hasan, Aliah B. Purwakania. Psikologi
Undang-undang No.12 Tahun 2006 tentang Kewarganegaraan. Idealnya, konsep usia dalam hukum nasional harus seragam untuk mewujudkan law inforcement di Indonesia.

Ketiga, upaya merekonstruksi batas usia perkawinan dalam hukum nasional Indonesia perpektif fikih adalah Pertama, upaya merubah ketentuan (klausul) batas usia dalam regulasi perkawinan dari usia minimal 16 tahun bagi perempuan dan 19 tahun bagi laki-laki dinaikkan menjadi 19 tahun bagi perempuan dan 21 tahun bagi laki-laki. Pada usia tersebut, khususnya anak perempuan telah menyelesaikan jenjang pendidikan SLTA. Selain itu, dengan mempertimbangkan aspek kematangan biologis, psikologis, dan sosial budaya. Sedangkan bagi laki-laki, usia 21 tahun telah memenuhi syarat untuk memikul tanggung jawab dan mampu (rusyd) menjadi pemimpin keluarga. Kedua, Pemberian izin dispensasi dengan syarat yang ketat dan sebaiknya diberi batas usia minimal dispensasi yakni usia 16 tahun bagi perempuan dan 19 tahun bagi laki-laki. Kedua konsep ini, dilihat dalam bingkai maslahah yang menjadi tujuan hukum Islam (maqas\}id al-syari'ah).

Perkembangan Islami: Menyingkap rentang Kehidupan Manusia dari Prakelahiran hingga Pascakematian. Jakarta: RajaGrafindo Persada, 2006

Karim,Helmi, “KedewasaanUntukMenikah" dalam Chuzaimah T. Yanggo dan Hafiz Anshary. Problematika Hukum Islam Kontemporer. Jakarta: Pustaka Firdaus, 1996

Katsier, Ibnu. Tafsir Ibnu Katsier. Mesir: Dar al-Kutub, t.th

Marzuki, Peter Mahmud. Penelitian Hukum. Jakarta: Kencana, 2009

Maulana, Misnan, "Perkawinan di Bawah Umur meningkat di Ponorogo." Tempo online, 06 September 2007. http://www. tempointeraktif.com. diakses 19 Mei 
2012

Mughniyah, Muhammad Jawad. Fikih Lima Mazhab. Jakarta: Lentera, 1999

Mulia,Musdah."MenujuHukumPerkawinan yangAdil:MemberdayakanPerempuan Indonesia", dalam Sulistyowati Irianto. Perempuan dan Hukum; Menuju Hukum yang Berperspektif Kesetaraan dan Keadilan. Jakarta: Yayasan Obor Indonesia, 2006.

Nuruddin dan Tarigan, Amiur dan Azhari Akmal.Hukum PerdataIslam diIndonesia; Studi Kritis Perkembangan Hukum Islam dari Fikih, UU No. 1/1974 sampai KHI. Jakarta: Kencana, 2006

Radjagukguk, Erman. dalam Yuliandri, Asas-asas Pembentukan Peraturan Perundang-undangan yang Baik. Jakarta: RajaGrafindo Persada, 2009

Republik Indonesia. Undang-undang No. 1 Tahun 1974 tentang Perkawinan. Surabaya: Pustaka Tinta Mas, 1990

Republik Indonesia.Undang-undang R.I No. 20 Tahun 2003 tentang Sistem Pendidikan Nasional. Jakarta: Biro Hukum dan Organisasi Sekretariat Jenderal Departemen Pendidikan Nasioanl, 2003.

Republik Indonesia.Undang-Undang R. I No. 3 Tahun 1997 tentang Pengadilan Anak. http://www.google.co.id. diakses 19 Mei 2012.

Republik Indonesia.Undang-Undang R. I No. 4 Tahun 1979 tentang Kesejahteraan Anak. http://www.google.co.id. diakses 19 Mei 2012 .

Republik Indonesia.Undang-Undang R.I No. 13 Tahun 2003 tentang Ketenagakerjaan. http://www.google.co.id. diakses 19 Mei 2012 .

Republik Indonesia. Undang-undang
R.I No. 12 Tahun 2006 tentang Kewarganegaraan. dalam Lian Nury Sanusi (Penyunting) Undangundang R.I No. 12 Tahun 2006 tentang Kewarganegaraan. Jakarta: Kawan Pustaka, 2006

Republik Indonesia. Undang-undang R.I No. 23 Tahun 2002 tentang Perlindungan Anak. dalam Syaiufullah (Penyusun) Undang-undang Rumah Tangga No. 23 Tahun 2004 E Undang-undang Perlindungan Anak No. 23 Tahun 2002. Padang: Baduose Media, 2008.

Republik Indonesia. Undang-undang R.I No. 23 Tahun 2006 tentang Administrasi Kependudukan, http://www.google. co.id. diakses 19 Mei 2012 .

Republik Indonesia. Undang-undang R.I No. 22 Tahun 2007 tentang Penyelenggaraan Pemilu, http://www.gagasmedia.com. diakses 19 Mei 2012.

Republik Indonesia. Kompilasi Hukum Islam. Surabaya: Karya Anda, t.th.

Ridha, Muhammad Rasyid. Tafsir al-Manar. Mesir: Al-Manar, 2000 M/1460 H

Samin, Sabri, "Eklektisisme Hukum Islam di Indonesia dalam Memaknai Ruang Privat dan Ruang Publik", (Makalah yang disajikan pada Seminar Hukum Islam di STAIN Menado, 13 April 2009)

Sofian dan Lubis, Misran dan Ahmad, "Pernikahan Dini dan Tuntutan Revisi UU Perkawinan," Waspada Online, 21 November 2008, http://www.waspada. co. id. diakses 19 Mei 2012

Sukardja, Ahmad, "Keberlakuan Hukum Agama dalam Tata Hukum Indonesia" dalam Cik Hasan Bisri, eds., Hukum Islam dalam Tatanan Masyarakat Indonesia. Jakarta: Logos, 1998 